EGU2020-5130, updated on 11 Mar 2021

https://doi.org/10.5194/egusphere-egu2020-5130

EGU General Assembly 2020

(c) Author(s) 2021. This work is distributed under

the Creative Commons Attribution 4.0 License.

\title{
Seismic wide-angle constrains on the structure of the northern Sicily margin and Vavilov Basin: implications for the opening of the Tyrrhenian back-arc basin
}

\author{
Ingo Grevemeyer ${ }^{1}$, Cesar Ranero ${ }^{2}$, Nevio Zitellini ${ }^{3}$, Valenit Sallares ${ }^{2}$, and Manel Prada ${ }^{2}$ \\ ${ }^{1}$ GEOMAR Helmholtz Centre of Ocean Research, RD4 - Marine Geodynamics, Kiel, Germany (igrevemeyer@geomar.de) \\ ${ }^{2}$ Instituto de Ciencias del Mar, CSIC, Barcelona, Spain \\ ${ }^{3}$ Institute of Marine Science, National Research Council, Bologna, Italy
}

The Tyrrhenian Sea in the central Mediterranean Sea was form by Neogene slab roll-back of the retreating Ionian slab about 6 to 2 Myr ago. Yet, little is known about the structure of its southern margin off Sicily as well as back-arc extension and spreading in the southern Tyrrhenian Sea to the north of Sicily. The Sicilian margin is generally classified as a passive margin bounding a young back-arc basin. However, focal mechanisms from regional earthquakes suggest that the margins suffers presently from compressional tectonics. New seismic refraction and wide-angle data were collected along seismic profile WAS4 during the CHIANTI survey of the Spanish research vessel Sarmiento de Gamboa in 2015. The profile runs from the centre of the Tyrrhenian Sea - the Vavilov Basin - across the margin of Sicily, approaching the Gulf of Castellammare to the northwest of Sicily. Reanalyzed multi-channel seismic data supports compressional tectonics across a small basin paralleling the coastline of Sicily, revealing recent inversion of the Tyrrhenian Basin. Offshore of Sicily WAS4 indicates a roughly 120-140 km wide domain showing seismic Pwave velocities characteristic for continental crust $(\mathrm{Vp} \sim 4-6.7 \mathrm{~km} / \mathrm{s})$ and a base of crust defined by a wide-angle Moho reflection. Continental crust reaches a maximum thickness of $22 \mathrm{~km}$ to the north of the Gulf of Castellammare and is thinning to $\sim 9 \mathrm{~km}$ to the north of the Ustica Ridge. The compressional belt occurs in continental crust to the south of Ustica Ridge. In the Vavilov Basin, a lithosphere was sample where seismic P-wave velocity increases from approx. 3-4 km/s to 7.5 $\mathrm{km} / \mathrm{s}$. This velocity depth-distribution clearly shows profound similarities to serpentinized mantle and hence un-roofed mantle. Thus, seismic constrains support results from Ocean Drilling Program (ODP) hole 651A, which sample serpentinized peridotites in the Vavilov Basin. The transition between serpentinized mantle and continental crust is rather abrupt. Thus, within a $\sim 10$ $\mathrm{km}$ wide transitional domain, continental crust with a thickness of $\sim 9 \mathrm{~km}$ is juxtaposed against unroofed mantle. All available data from the Tyrrhenian Sea support wide-spread mantle exhumation in the Vavilov Basin. Therefore, the Tyrrhenian Sea provides a rather different structure when compared to marginal basins in the Western Pacific and hence may not have supported a mid-ocean ridge-type spreading system opening the basin. 